Praca oryginalna/Original research article

\title{
Zakażenia wirusowe u dzieci po przeszczepieniu komórek krwiotwórczych
}

\section{Viral infections in children undergoing hematopoietic stem cell transplantation}

\section{Jan Styczyński ${ }^{1, *}, K^{2} z y s z t o f$ Czyżewski ${ }^{1}$, Karolina Siewiera ${ }^{2}$, Jowita Frączkiewicz ${ }^{2}$, Olga Zając-Spychała ${ }^{3}$, Jolanta Goździk ${ }^{4}$,} Agnieszka Zaucha-Prażmo ${ }^{4}$, Krzysztof Kałwak ${ }^{2}$, Ewa Gorczyńska ${ }^{2}$, Alicja Chybicka ${ }^{2}$, Jacek Wachowiak ${ }^{3}$, Jerzy Kowalczyk ${ }^{5}$, Mariusz Wysocki ${ }^{1}$

\footnotetext{
${ }^{1}$ Katedra Pediatrii, Hematologii i Onkologii, Collegium Medicum, Uniwersytet Mikołaja Kopernika, Szpital Uniwersytecki nr $1 \mathrm{im}$. dr. A. Jurasza, Kierownik: prof. dr hab. Mariusz Wysocki, Bydgoszcz, Polska

${ }^{2}$ Katedra i Klinika Transplantacji Szpiku, Onkologii i Hematologii Dziecięcej, Uniwersytet Medyczny,

Kierownik: prof. dr hab. Alicja Chybicka, Wrocław, Polska

${ }^{3}$ Klinika Onkologii, Hematologii i Transplantologii Pediatrycznej, Uniwersytet Medyczny, Kierownik: prof. dr hab. Jacek Wachowiak, Poznań, Polska

${ }^{4}$ Ośrodek Transplantacji Uniwersyteckiego Szpitala Dziecięcego w Krakowie, Katedra Immunologii i Transplantologii Klinicznej, Uniwersytet Jagielloński Collegium Medicum, Kierownik: dr hab. Jolanta Goździk, Kraków, Polska

${ }^{5}$ Klinika Hematologii, Onkologii i Transplantologii Dziecięcej, Uniwersytet Medyczny, Kierownik: prof. dr hab. Jerzy Kowalczyk, Lublin, Polska
}

INFORMACJE O ARTYKULE

Historia artykułu:

Otrzymano: 14.02.2015

Zaakceptowano: 20.03.2015

Dostępne online: 31.03.2015

Słowa kluczowe:

- zakażenia wirusowe

- choroby nowotworowe

- onkohematologia

- przeszczepianie komórek

krwiotwórczych

- dzieci

\begin{abstract}
A B S T R A C T
Background: Due to clinical reasons, in stem cell transplant setting viral infections are divided as latent (herpesviruses, BKV) and sporadic (adenovirus - ADV, rotavirus - RV, influenza - INFL and others). Objective: The aim of this study was the analysis of incidence and outcome of viral infections in 5 Polish pediatric hematopoietic stem cell transplantation (HSCT) centers. Patients and methods: A total number of 308 HSCTs (allo 232, auto - 76) performed over a period of 24 months in children and adolescents in participating centers were analyzed retrospectively. Results: In the period under analysis, 205 viral infections were diagnosed (197 after allo-HSCT, and 8 after auto-HSCT). After allo-HSCT, infections occurred in 119 (51.3\%) patients, of which 51.2\% were one of multiple infections: 58 patients were infected with one virus, 29 with two, 16 with three and 16 with four or more viruses. Cumulative incidence of viral infections after alloHSCT was: CMV - 28.0\%, BKV - 18.5\%, EBV - 15.5\%, ADV - 9.5\%, RV - 9.1\%, VZV - 2.6\%,
\end{abstract}

\footnotetext{
* Adres do korespondencji: Katedra Pediatrii, Hematologii i Onkologii Collegium Medicum im. L. Rydygiera w Bydgoszczy Uniwersytet Mikołaja Kopernika, ul. Curie-Skłodowskiej 9, 85-094 Bydgoszcz, Polska.

Adres email: jstyczynski@cm.umk.pl (J. Styczyński).

http://dx.doi.org/10.1016/j.achaem.2015.03.004

0001-5814/@ 2015 Polskie Towarzystwo Hematologów i Transfuzjologów, Instytut Hematologii i Transfuzjologii. Published by Elsevier Sp. $\mathrm{z}$ o.o. All rights reserved.
} 
Keywords:

- Viral infections

- Malignant diseases

- Pediatric hematology and oncology

- Hematopoietic stem cell transplantation

- Children
INFL $-0.9 \%$, HHV6 - 0.9\%. In $8(10.5 \%)$ auto-HSCT patients following infections were diagnosed: RV - 4, CMV - 2, ADV - 1, BKV - 1. With respect to specific virus, there were no differences between patients' age and time from HSCT to beginning of infection (medians: 0.8-2.4 month), except for late VZV infection occurring at median time of 6.5 month after HSCT. Cure rates were lowest for: EBV (90,7\%), ADV (93,8\%), BKV (94,2\%), CMV (94,6\%), and reached $100 \%$ in case of INFL, HBV, VZV, HHV6 and RV. Conclusions: Viral infections in children after HSCT occur in over $50 \%$ of the patients after allo-HSCT and $10 \%$ after auto-HSCT. Mixed and multiple infections occur frequently. Infections with CMV, EBV, BKV or ADV contribute to deaths in $5-10 \%$ patients.

(C) 2015 Polskie Towarzystwo Hematologów i Transfuzjologów, Instytut Hematologii i Transfuzjologii. Published by Elsevier Sp. z o.o. All rights reserved.

\section{Wstęp}

Powikłania infekcyjne są jednym z głównych czynników wpływających na śmiertelność po chemioterapii i allo-HSCT. Dane rejestru CIBMTR pokazują, że wśród przyczyn niepowodzeń przeszczepiania komórek krwiotwórczych (HSCT; hematopoietic stem cell transplantation) zakażenia są przyczyną $12 \%$ zgonów po HSCT od zgodnych dawców rodzinnych, 17\% zgonów po HSCT od dawców niespokrewnionych i $8 \%$ po auto-HSCT [1]. Dane amerykańskie wykazują, że zakażenia po allo-HSCT występują u $82 \%$ dzieci [2], natomiast po autoHSCT u $21 \%$ dzieci z guzami litymi i chłoniakami oraz u $49 \%$ u dzieci z ostrymi białaczkami [3]. Częstość zakażeń wirusowych u dzieci po auto-HSCT wynosi 11\% [3], natomiast po allo-HSCT sięga $20 \%$ pacjentów do dnia +30 , około $18 \%$ pomiędzy dniami +30 i +100 oraz $19 \%$ pacjentów po dniu +100 [2]. Najczęstsze zakażenia wirusowe u dzieci niezależnie od rodzaju przeszczepienia to reaktywacje HSV (herpes simplex virus) we wczesnym okresie potransplantacyjnym oraz zakażenia wirusem cytomegalii (CMV) po allo-HSCT i VZV (varicella-zoster virus) po auto-HSCT [2, 3]. Zakażenia przyczyniają się do zgonów 8\% dzieci poddawanych allo-HSCT, w tym zakażenia grzybicze w 53\%, zakażenia bakteryjne w $20 \%$, wirusowe w $24 \%$ i pasożytnicze w $3 \%$ wszystkich zgonów [2]. Zgony z powodu infekcji u dzieci poddawanych auto-HSCT zdarzają się rzadko [3].

Analiza autopsyjna pacjentów po transplantacjach wykazała, że infekcje są przyczyną 55\% zgonów po allo-HSCT oraz $18 \%$ po auto-HSCT [4]. W analizie wielowariantowej czynnikiem wpływającym istotnie na śmiertelność po alloHSCT okazało się zakażenie CMV [5] i inwazyjne zakażenia grzybicze [6]. Natomiast zakażenia bakteryjne miały istotny wpływ na śmiertelność w analizie jednowariantowej, lecz nie $\mathrm{w}$ analizie wielowariantowej [6].

Ze względów klinicznych, w oddziałach przeszczepowych wyróżnia się zakażenia wirusami latentnymi (głównie herpeswirusy i polyomawirusy - BKV) i sporadycznymi (adenowirus - ADV, rotawirus - RV, grypa - INFL i inne) [7] (Tab. I).

Celem pracy była analiza epidemiologiczna zakażeń wirusowych u dzieci i młodzieży poddawanych przeszczepieniu komórek krwiotwórczych w 5 ośrodkach Polskiej Pediatrycznej Grupy ds. Przeszczepiania Komórek Krwiotwórczych (PPGdsPKK).

\section{Material i metody}

Retrospektywnej analizie poddano 308 transplantacji komórek krwiotwórczych przeprowadzonych u dzieci i młodzieży w latach 2012-2013 w 5 polskich pediatrycznych ośrodkach przeszczepowych. W zależności od typu przeszczepienia wykonano 232 allo-HSCT oraz 76 auto-HSCT. W zależności od typu ostrej białaczki wykonano 67 przeszczepień u pacjentów z ostrą białaczką limfoblastyczną (ALL; acute lymphoblastic leukemia) oraz 47 u pacjentów z ostrą białaczką mieloblastyczną (AML; acute myeloblastic leukemia).

Analizowano częstość występowania oraz metody i wyniki leczenia zakażeń wirusami latentnymi (CMV, EBV, VZV, HHV6, polioma BK) i sporadycznymi (ADV, INFL, RV).

Tabela I - Rodzaje i częstość występowania wirusów w populacji

Table I - Types and frequency of viral infections in population

ZAKAŻENIA LATENTNE

\begin{tabular}{lc}
\hline Wirus & $\begin{array}{c}\text { Odsetek osób } \\
\text { seropozytywnych }\end{array}$ \\
\hline HSV1/2 (Herpes Simplex Virus) & $50-90 \%$ \\
VZV (Varicella-Zoster Virus) & $90 \%$ \\
CMV (Cytomegalovirus) & $45-90 \%$ \\
HHV-6 (Human Herpes Virus 6) & $90 \%$ \\
EBV (Epstein-Barr Virus) & $90 \%$ \\
BKV (BK Polyomavirus) & $90 \%$
\end{tabular}

ZAKAŻENIA EPIZODYCZNE

\begin{tabular}{lc}
\hline \multicolumn{1}{c}{ Wirus } & $\begin{array}{c}\text { Odsetek osób zakażonych } \\
\text { w trakcie endemii }\end{array}$ \\
\hline RSV (Respiratory Syncytial Virus) & $5-15 \%$ \\
Parainfluenza & $5-10 \%$ \\
Influenza & $5 \%$ \\
Adenovirus & $5 \%$ \\
Rhinovirus & $5 \%$ \\
Odra & $1 \%$ \\
\hline
\end{tabular}




\section{Analiza statystyczna}

Częstość występowania zakażeń porównano testem $\chi^{2}$. Częstości kumulacyjne występowania zakażeń oraz śmiertelność zależną od infekcji wirusowej (IRM; infection-related mortality) wyznaczono metodą Kaplana-Meiera i porównano testem logrank. Ryzyko wystąpienia zakażenia określono w modelu Coxa.

\section{Wyniki}

\section{Częstość zakażeń}

W analizowanym okresie stwierdzono 205 zakażeń wirusowych (197 po allo-HSCT, 8 po auto-HSCT). U pacjentów po allo-HSCT zakażenia wystąpiły u 119 (51,3\%), w tym u ponad połowy z nich $(51,2 \%)$ zakażenia wielokrotne: u 58 pacjentów obserwowano zakażenie jednym wirusem, u 29 - dwoma, u 16 - trzema i u 16 - czterema lub więcej.

Nie stwierdzono różnic $\mathrm{w}$ wieku pacjentów oraz medianie czasu od transplantacji do stwierdzenia zakażenia (mediany od 0,8 do 2,4 miesiąca) między grupami pacjentów zakażonych poszczególnymi wirusami (Ryc. 1). Jedynie w przypadku zakażenia VZV obserwowano dłuższy czas od transplantacji do wystąpienia zakażenia (mediana 6,5 miesiąca) (Tab. II).

Częstość kumulacyjna zakażeń po allo-HSCT wynosiła: CMV - 28,0\%, BKV - 18,5\%, EBV - 15,5\%, ADV - 9,5\%, RV - 9,1\%, VZV - 2,6\%, INFL - 0,9\%, HHV6 - 0,9\% (Ryc. 2). U 8 (10,5\%) pacjentów po auto-HSCT wystąpiły następujące zakażenia: RV - 4, CMV - 2, ADV - 1, BKV - 1. Stwierdzono tylko jedno zakażenie HBV, nie odnotowano żadnego zakażenia HCV.

\section{Wyniki terapii}

W terapii zakażeń CMV w pierwszej linii stosowano gancyklowir lub foskarnet, w drugiej lub trzeciej linii cydofowir,
Tabela II - Wiek, czas do zakażenia i czas terapii zakażeń wirusowych po allo-HSCT

Table II - Age, time to infection and time of treatment of viral infections after allo-HSCT

\begin{tabular}{lccc} 
& Wiek [lata] & $\begin{array}{c}\text { Czas od HSCT } \\
\text { do zakażenia } \\
\text { [miesiące] }\end{array}$ & $\begin{array}{c}\text { Czas } \\
\text { leczenia } \\
\text { [dni] }\end{array}$ \\
\hline ADV & $7,4(0-18,7)$ & $2,4(-0,3-13,7)$ & $18(0-101)$ \\
BKV & $12,7(0-19)$ & $0,8(-0,1-12,5)$ & $19(1-135)$ \\
CMV & $10,7(0-19)$ & $1,1(0,4-13,2)$ & $21(5-167)$ \\
EBV & $9,2(0,5-19)$ & $2(0,5-11)$ & $7(0-168)$ \\
FLU & $9,3(3,6-14,9)$ & $1,7(1,4-2)$ & $9(7-11)$ \\
ROTA & $4,7(0,5-18,7)$ & $1,2(-0,4-5,8)$ & $7,5(0-11)$ \\
VZV & $13,6(7,1-14,8)$ & $6,5(3,1-9,0)$ & $15(10-47)$ \\
HHV6 & $2,3(2,3-3,5)$ & $1,3(1,2-2,1)$ & $21(10-22)$ \\
\hline
\end{tabular}

natomiast w części przypadków również walgancyklowir jako doustną terapię podtrzymującą. Terapia krwotocznego zapalenia pęcherza moczowego o etiologii polioma BKV była prowadzona zazwyczaj z użyciem cydofowiru. Terapia zakażeń EBV, zarówno wyprzedzająca w EBV-DNA-emii, jak też klinicznie jawnego zespołu limfoproliferacyjnego była oparta na rytuksymabie. Zakażenia adenowirusem były leczone cydofowirem; zakażenia VZV acyklowirem, zakażenia HHV6 foskarnetem lub gancyklowirem; a wirusem grypy oseltamiwirem. Zakażenia rotawirusem były leczone objawowo.

W przypadku zakażeń wirusami sporadycznymi mediana czasu trwania terapii wynosiła 1-2 tygodni, natomiast w przypadku zakażeń wirusami latentnymi około 3 tygodnie, a w pojedynczych przypadkach terapia trwała ponad $100 \mathrm{dni}$ (Tab. II).

Odsetek wyleczeń z poszczególnych infekcji był najniższy w przypadku zakażenia EBV (90,7\%), ADV (93,8\%), BKV (94,2\%), CMV (94,6\%), natomiast wynosił 100\% w przypadku zakażeń INFL, VZV, HHV6 i RV (Tab. III).

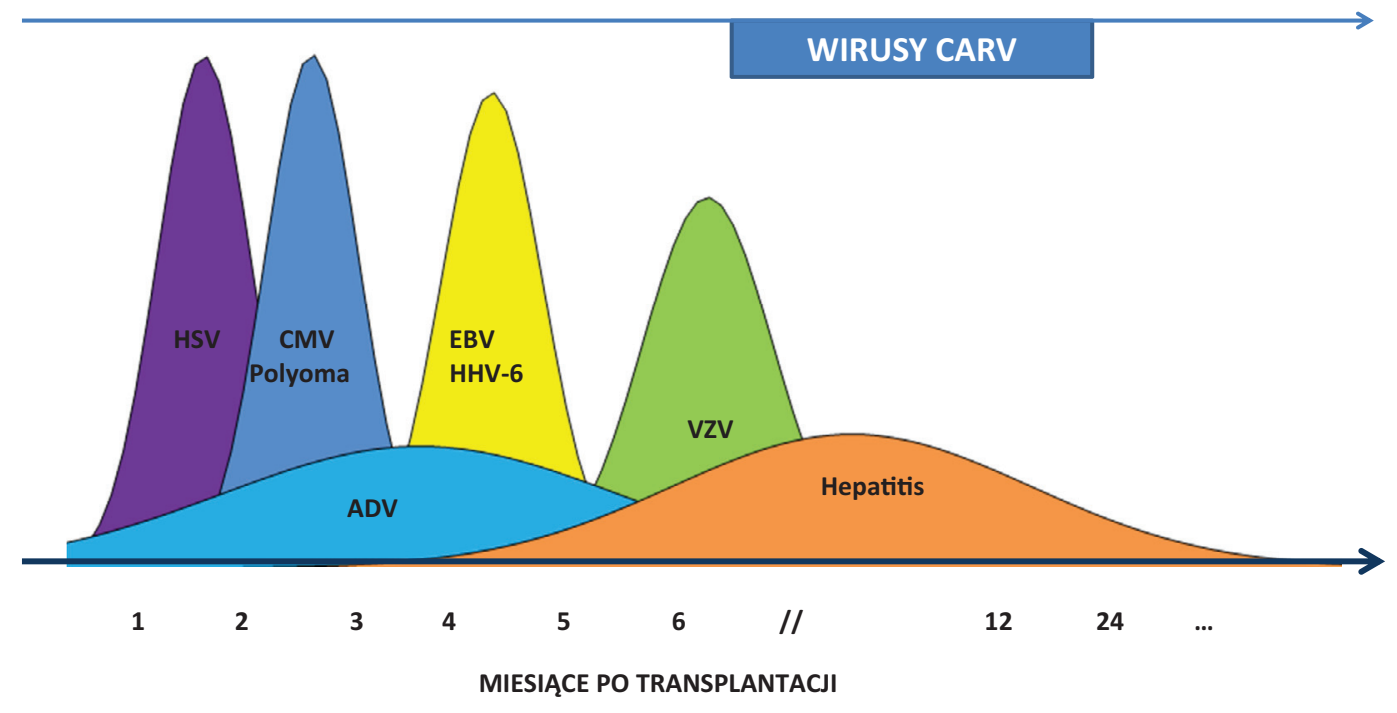

Ryc. 1 - Czas występowania zakażeń wirusowych po allo-HSCT

Fig. 1 - Timing of occurrence of vital infections after allo-HSCT 


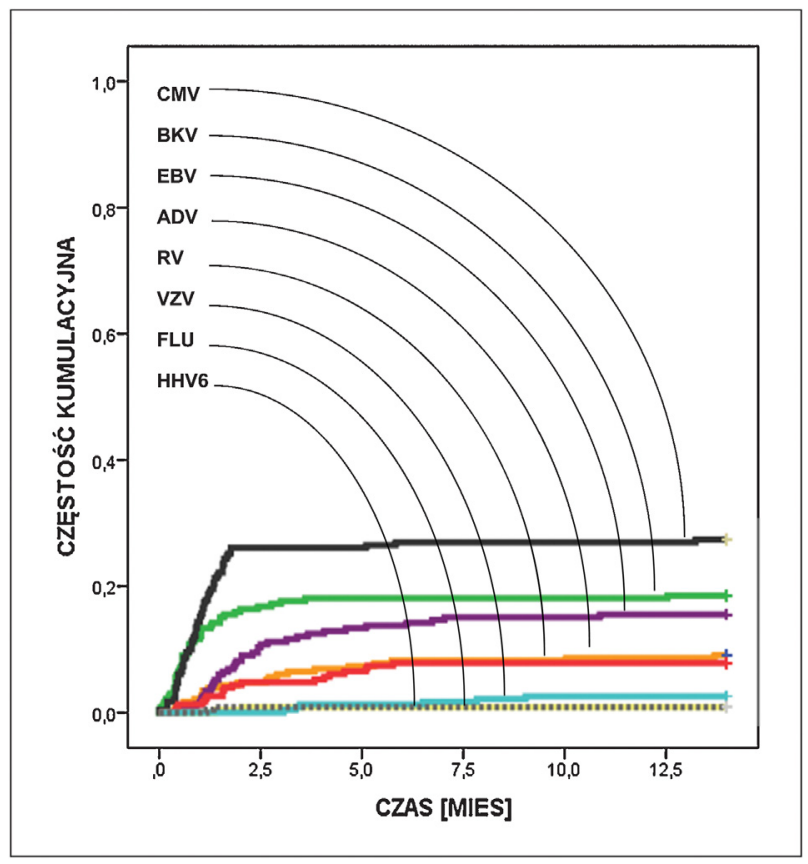

Ryc. 2 - Częstość kumulacyjna zakażeń wirusowych po HSCT

Fig. 2 - Cumulative incidence of viral infections after HSCT

\section{Omówienie}

Prezentowana analiza jest pierwszym polskim opracowaniem dotyczącym epidemiologii zakażeń wirusowych u dzieci po HSCT oraz wyników leczenia tych zakażeń, z uwzględnieniem wszystkich krajowych dziecięcych ośrodków przeszczepowych. Analiza objęła okres kolejnych 24 miesięcy. Można więc przyjąć, że standardy postępowania profilaktycznego, diagnostycznego i terapeutycznego były bardzo porównywalne dla wszystkich ośrodków i wszystkich pacjentów [8]. Z przeprowadzonej analizy wynika, że odsetek dzieci po HSCT, u których dochodzi do zakażeń wirusowych, jest wysoki i sięga 51\% pacjentów po allo-HSCT i $10 \%$ po auto-HSCT.

Dane o częstości występowania zakażeń wirusowych u dzieci po allo-HSCT są stosunkowo nieliczne. Najczęściej ocenia się, że zakażenia lub reaktywacje wirusów latentnych występują u 10-20\% pacjentów [2, 3, 9]. Zakażenia wirusowe występują w trakcie limfopenii komórek CD4 z częstością: 16\% CMV, 15\% ADV, 11\% EBV [9]. Stosunkowo wysoka częstość zakażeń CMV, BKV i EBV może być następstwem immunosupresji po HSCT oraz poprzedzających tę procedurę cyklach terapii.

Najczęstsze i najgroźniejsze dla pacjentów są reaktywacje zakażenia CMV. Zakażenie to może powodować niewydolność szpiku, zapalenie płuc, zapalenia jelit, rzadziej zapalenia wątroby lub zapalenie siatkówki. Reaktywacje CMV występują najczęściej u pacjentów poddanych silnej immunosupresji po allo-HSCT. Teoretycznie najlepszym leczeniem byłoby odstawienie terapii immunosupresyjnej, jednak najczęściej jest to niemożliwe. W diagnostyce CMV stosuje się ilościowe oznaczanie DNA-emii, a w strategii terapeutycznej najczęściej stosuje się leczenie wyprzedzające gancyklovirem lub foscarnetem, a także valgancyklovirem w terapii podtrzymującej [10]. W ostatnim okresie pojawiły się doniesienia o skuteczności nowych leków, takich jak brincidofowir (liposomalny cidofovir), maribawir i letermowir [11]. W terapii opornych lub nawracających zakażeń CMV stosuje się leczenie skojarzone lub cydofowir, a w niektórych krajach terapię komórkową z zastosowaniem CMV-specyficznych cytotoksycznych limfocytów T [10]. Oporność zakażenia CMV na terapię należy podejrzewać w przypadku: a) przedłużonej >6 tygodni ekspozycji na lek p/CMV, b) braku spadku DNA-emii po 3 tygodniach terapii, c) postępu choroby po przedłużonej terapii p/CMV [12].

Zakażenia EBV pojawiają się najczęściej w postaci DNAemii, której może towarzyszyć gorączka i limfadenopatia [13]. Najcięższą postacią zakażenia EBV jest poprzeszczepowy zespół limfoproliferacyjny (PTLD; post-transplant lymphoproliferative disorder). Jeszcze półtorej dekady temu była to choroba śmiertelna, jednak obecnie dzięki zastosowaniu metody PCR w strategii diagnostycznej oraz rytuksymabu w terapii wyprzedzającej i celowanej, choroba ta jest uleczalna w 70-80\% przypadków [14-17].

Tabela III - Terapia zakażeń wirusowych i jej wyniki po allo-HSCT Table III - Treatment and outcome of viral infections after allo-HSCT

\begin{tabular}{|c|c|c|c|c|c|c|}
\hline Wirus & $\mathrm{N}$ & Terapia celowana & $\begin{array}{c}\text { Terapia } \\
\text { objawowa }\end{array}$ & Przeżyli & IRM & Przeżycie (\%) \\
\hline CMV & 93 & $\begin{array}{l}\text { Gancyklowir }(n=69)^{*} \text { Foskarnet }(n=36) \text { Cydofowir }(n=13) \\
\text { Walgancyklowir }(n=11)\end{array}$ & 1 & 88 & $5(5,4 \%)$ & $94,6 \%$ \\
\hline BKV & 53 & $\begin{array}{l}\text { Cydofowir }(n=35) \text { Gancyklowir }(n=6) \text { Foskarnet }(n=3) \\
\text { Ciprofloksacyna }(n=9)\end{array}$ & 11 & 49 & $3(5,8 \%)$ & $94,2 \%$ \\
\hline EBV & 43 & Rytuksymab $(\mathrm{n}=36)$ & 7 & 39 & $4(9,3 \%)$ & $90,7 \%$ \\
\hline ADV & 32 & Cydofowir $(\mathrm{n}=14)$ & 18 & 30 & $2(6,2 \%)$ & $93,8 \%$ \\
\hline VZV & 7 & Acyklowir $(\mathrm{n}=7)$ & 0 & 7 & 0 & $100 \%$ \\
\hline HHV6 & 3 & Foskarnet $(\mathrm{n}=2)$ Gancyklowir $(\mathrm{n}=1)$ & 0 & 3 & 0 & $100 \%$ \\
\hline INFL & 2 & Oseltamiwir $(n=2)$ & 0 & 2 & 0 & $100 \%$ \\
\hline RV & 27 & & 27 & 27 & 0 & $100 \%$ \\
\hline
\end{tabular}


W związku z profilaktycznym stosowaniem acyklowiru, reaktywacje zakażeń VZV występują obecnie stosunkowo rzadko. Starszy wiek jest uznawany za czynnik ryzyka wystąpienia VZV, również u dzieci $[18,19]$. Aktualnie zaleca się stosowanie acyklowiru u pacjentów seropozytywnych przez co najmniej rok po allo-HSCT [14].

Problemem u dzieci po HSCT są zakażenia ADV, które mogą przyjmować różne postaci. W badaniach przesiewowych, częstość zakażeń ADV u dzieci po HSCT wynosiła 6-28\%, podczas gdy u pacjentów dorosłych 0-6\% [20]. Aktualna strategia postępowania diagnostyczno-terapeutycznego dla pacjentów po HSCT rekomenduje diagnostykę opartą na badaniu PCR krwi obwodowej oraz terapię cydofowirem [20].

W naszej analizie stwierdziliśmy stosunkowo niski odsetek pacjentów z objawowym zakażeniem wirusem grypy. Może to być efektem dobrej profilaktyki środowiskowej. Rekomendacje ECIL zalecają diagnostykę opartą na badaniu PCR materiału pobranego z zainfekowanego układu oddechowego, najlepiej z popłuczyn pęcherzykowo-oskrzelikowych (BAL) oraz terapię oparta na stosowaniu inhibitorów neuraminidazy, np. oseltamiwir [21].

Odsetek zakażeń wirusowych układu oddechowego był stosunkowo niski. W badaniach prospektywnych Ljungmana i wsp. u dzieci i dorosłych po auto-HSCT wynosił on $0,4 \%$ w obserwacji 30-miesięcznej [22]. Uważa się jednak, że dzieci bardziej niż dorośli są podatne na wirusowe zakażenia układu oddechowego, a po zakażeniu wirus dłużej pozostaje w organizmie dziecka. I tak, w badaniach koreańskich u dzieci po HSCT odsetki zakażeń wyniosły: 28,1\% dla rhinowirusa, 25,8\% dla RSV, 18\% dla PIV3 (parainfluenza), $13,5 \%$ dla ADV i 11,2\% dla coronawirusa [23]. Wydaje się, że na dzień dzisiejszy najlepszą metodą diagnostyczną jest badanie multiplex PCR, a materiałem diagnostycznym jest wymaz z gardła [24]. W terapii zakażeń wirusami oddechowymi rekomenduje się rybawirinę i IGIV w zakażeniach RSV, PIV i MPV, natomiast brak jest wystarczających dowodów do specyficznej rekomendacji wobec zakażeń powodowanych przez coronawirus lub rhinowirus [25].

W pracy analizie poddano również zakażenia rotawirusem, gdyż polskie prawodawstwo uznaje go za patogen alarmowy. U pacjentów po HSCT patogen ten nie stanowił jednak istotnego problemu klinicznego, a typowe leczenie objawowe było skuteczne u wszystkich zainfekowanych pacjentów.

\section{Wnioski}

1. Zakażenia wirusowe u dzieci po przeszczepieniu komórek krwiotwórczych dotyczą ponad $50 \%$ pacjentów po alloHSCT i $10 \%$ po auto-HSCT. Często stwierdza się współistnienie infekcji.

2. Wirusy CMV, EBV, BKV i ADV przyczyniają się do zgonu w 5-10\% zakażeń, zwłaszcza w przypadku współistnienia zakażeń.

\section{Wkład autorów/Authors' contributions}

JS, KC - koncepcja pracy, analiza danych, zebranie i interpretacja danych, napisanie artykułu, zebranie piśmiennictwa, akceptacja artykułu. KS, JF, OZ-S, JG, AZ-P, KK, EG, AC, JW, JK, MW - zebranie i interpretacja danych, akceptacja artykułu.

\section{Konflikt interesu/Conflict of interest}

Nie występuje.

\section{Finansowanie/Financial support}

Nie występuje.

\section{Etyka/Ethics}

Treści przedstawione $\mathrm{w}$ artykule są zgodne $\mathrm{z}$ zasadami Deklaracji Helsińskiej, dyrektywami EU oraz ujednoliconymi wymaganiami dla czasopism biomedycznych.

\section{PIŚ M I E N N IC T W O/REFERENCES}

[1] Pasquini MC, Wang Z. Current use and outcome of hematopoietic stem cell transplantation: CIBMTR Summary Slides. Available at: http://www.cibmtr.org 2013.

[2] Srinivasan A, Wang C, Srivastava DK, et al. Timeline, epidemiology, and risk factors for bacterial, fungal, and viral infections in children and adolescents after allogeneic hematopoietic stem cell transplantation. Biol Blood Marrow Transplant 2013;19:94-101.

[3] Srinivasan A, McLaughlin L, Wang C, et al. Early infections after autologous hematopoietic stem cell transplantation in children and adolescents: the St. Jude experience. Transpl Infect Dis 2014;16:90-97.

[4] Sinko J, Csomor J, Barta A, et al. Infection-related deaths in the haematopoietic stem cell transplant setting. Bone Marrow Transplant 2012;47(suppl. 1). abstract 472.

[5] Bjorklund A, Aschan J, Labopin M, et al. Risk factors for fatal infectious complications developing late after allogeneic stem cell transplantation. Bone Marrow Transplant 2007; 40:1055-1062.

[6] Martino R, Kerguelen A, Valcarcel D, et al. Reduction of infection-related mortality after allogeneic PBSCT from HLA-identical siblings: longitudinal analysis from 1994 to 2008 at a single institution. Bone Marrow Transplant 2011;46:690-701.

[7] Marr KA. Delayed opportunistic infections in hematopoietic stem cell transplantation patients: a surmountable challenge. Hematology Am Soc Hematol Educ Program 2012;2012:265-270.

[8] Styczynski J, Gil L. Prevention of infectious complications in pediatric HSCT. Bone Marrow Transplant 2008;42 Suppl 2: S77-S81.

[9] Hiwarkar P, Gaspar HB, Gilmour K, et al. Impact of viral reactivations in the era of pre-emptive antiviral drug therapy following allogeneic haematopoietic SCT in paediatric recipients. Bone Marrow Transplant 2013;48:803-808.

[10] Ljungman P, de la Camara R, Cordonnier C, et al. Management of CMV, HHV-6, HHV-7 and Kaposi-sarcoma herpesvirus (HHV-8) infections in patients with hematological malignancies and after SCT. Bone Marrow Transplant 2008;42:227-240. 
[11] Griffiths P, Lumley S. Cytomegalovirus. Curr Opin Infect Dis 2014;27:554-559.

[12] Kotton CN, Kumar D, Caliendo AM, et al. Updated international consensus guidelines on the management of cytomegalovirus in solid-organ transplantation. Transplantation 2013;96:333-360.

[13] Styczynski J, Einsele H, Gil L, Ljungman P. Outcome of treatment of Epstein-Barr virus-related post-transplant lymphoproliferative disorder in hematopoietic stem cell recipients: a comprehensive review of reported cases. Transpl Infect Dis 2009;11:383-392.

[14] Styczynski J, Reusser P, Einsele H, et al. Management of HSV, VZV and EBV infections in patients with hematological malignancies and after SCT: guidelines from the Second European Conference on Infections in Leukemia. Bone Marrow Transplant 2009;43:757-770.

[15] Styczynski J, Gil L, Tridello G, et al. Response to rituximabbased therapy and risk factor analysis in epstein barr virusrelated lymphoproliferative disorder after hematopoietic stem cell transplant in children and adults: a study from the Infectious Diseases Working Party of the European Group for Blood and Marrow Transplantation. Clin Infect Dis 2013;57:794-802.

[16] Gil L, Styczynski J, Komarnicki M. Strategy of pre-emptive management of Epstein-Barr virus post-transplant lymphoproliferative disorder after stem cell transplantation: results of European transplant centers survey. Contemp Oncol (Pozn) 2012;16:338-340.

[17] Czyzewski K, Styczynski J, Krenska A, et al. Intrathecal therapy with rituximab in central nervous system involvement of post-transplant lymphoproliferative disorder. Leuk Lymphoma 2013;54:503-506.

[18] Berman JN, Wang M, Berry W, et al. Herpes zoster infection in the post-hematopoietic stem cell transplant pediatric population may be preceded by transaminitis: an institutional experience. Bone Marrow Transplant 2006;37:73-80.

[19] Lewin SR, Heller G, Zhang L, et al. Direct evidence for new $\mathrm{T}$-cell generation by patients after either $\mathrm{T}$-cell-depleted or unmodified allogeneic hematopoietic stem cell transplantations. Blood 2002;100:2235-2242.

[20] Matthes-Martin S, Feuchtinger T, Shaw PJ, et al. European guidelines for diagnosis and treatment of adenovirus infection in leukemia and stem cell transplantation: summary of ECIL-4 (2011). Transpl Infect Dis 2012;14:555-563.

[21] Engelhard D, Mohty B, de la Camara R, et al. European guidelines for prevention and management of influenza in hematopoietic stem cell transplantation and leukemia patients: summary of ECIL-4 (2011), on behalf of ECIL, a joint venture of EBMT, EORTC, ICHS, and ELN. Transpl Infect Dis 2013;15:219-232.

[22] Ljungman P, Ward KN, Crooks BN, et al. Respiratory virus infections after stem cell transplantation: a prospective study from the Infectious Diseases Working Party of the European Group for Blood and Marrow Transplantation. Bone Marrow Transplant 2001;28:479-484.

[23] Choi JH, Choi EH, Kang HJ, et al. Respiratory viral infections after hematopoietic stem cell transplantation in children. J Korean Med Sci 2013;28:36-41.

[24] Mikulska M, Del Bono V, Gandolfo N, et al. Epidemiology of viral respiratory tract infections in an outpatient haematology facility. Ann Hematol 2014;93: 669-676.

[25] Hirsch HH, Martino R, Ward KN, et al. Fourth European Conference on Infections in Leukaemia (ECIL-4): guidelines for diagnosis and treatment of human respiratory syncytial virus, parainfluenza virus, metapneumovirus, rhinovirus, and coronavirus. Clin Infect Dis 2013;56:258-266. 